\title{
Cardiac Epithelioid Hemangioendothelioma
}

National Cancer Institute

\section{Source}

National Cancer Institute. Cardiac Epithelioid Hemangioendothelioma. NCI Thesaurus. Code C5362.

A low-grade malignant blood vessel neoplasm, arising from the heart. Ilt is characterized by the presence of epithelioid endothelial cells. The neoplastic cells are arranged in cords and nests, which are embedded in a myxoid to hyalinized stroma. 